\title{
Production of Japanese Horseradish (Wasabia japonica (Miq.) Matsumara) in Poland. Chemical Contents of Roots
}

\section{Anna GAŁCZYŃSKA ${ }^{1 *}$, Paulina TRZCINSKA ${ }^{1}$, Małgorzata GUMIENNA ${ }^{2}$, Jacek NOWAK ${ }^{2}$, Roman HOEUBOWICZ ${ }^{1}$}

\author{
${ }^{1}$ Poznań University of Life Sciences, Department of Plant Pathology, Seed Science and Technology, Seed Science and Technology Division, \\ Baranowo, ul. Szamotulska 28, 62-081, Przeźmierowo, Poland; aniagalcz@gmail.com (*corresponding author); \\ trzcinskapaulina.wrz@gmail.com; rbseed@up.poznan.pl \\ ${ }^{2}$ Poznań University of Life Sciences, Department of Fermentation and Biosynthesis, Institute of Food Technology of Plant Origin, Faculty of Food \\ Science and Nutrition, ul.Wojska Polskiego 31,60-624 Poznań,Poland; gumienna@up.poznan.pl;jacnow@up.poznan.pl
}

\begin{abstract}
Japanese horseradish [Wasabia japonica (Miq.) Matsumara or Eutrema wasabi (Siebold) Maxim.], is a vegetable species originated from Japan. Currently, wasabi is grown in many other countries across the world such as: New Zealand, Taiwan, South Korea, Israel, Brazil, Thailand, Columbia, Canada, USA, Great Britain and China. The crop has never been cultivated commercially in Poland. The main aim of the present study was to find out if the crop can be grown commercially in Poland and to establish the chemical contents of roots produced in Poland and Japan. In previous studies, it was noted that wasabi might be grown under polycarbonate cover in Poland. The chemical evaluation included measuring the amount of dry matter, polyphenols, antioxidant potential, reducing substances, total proteins, starch and raw fiber. The roots produced in Poland had more dry matter (30.46\%), less total proteins $(12.14 \%)$ and reducing substances $\left(43.64 \mathrm{mg} \mathrm{g}^{-1}\right)$ than the Japanese ones. Starch and raw fiber contents were on the same level in the roots produced in both countries. The antioxidant potential and polyphenols in the Japanese roots $\left(6.11 \mathrm{mg} \mathrm{g}^{-1}\right.$ and $7.83 \mathrm{mg} \mathrm{g}^{-1}$ respectively) were higher than in the Polish ones $\left(1.45 \mathrm{mg} \mathrm{g}^{-1}\right.$ and $3.25 \mathrm{mg} \mathrm{g}^{-1}$ respectively ). In the climatic conditions of Poland, it might be possible to produce wasabi roots under the polycarbonate cover with their chemical contents at least in part similar to the original roots produced in Japan.
\end{abstract}

Keywords: Eutrema wasabi (Siebold) Maxim., chemical constituents, wasabi production, wasabi root

\section{Introduction}

Wasabi, also called Japanese horseradish is a brassicous vegetable, popular in Japan. Its use there is similar to wellknown horseradish (Armoracia rusticana G. M. Sch.) in Europe. However, the latter is less spicy in taste than the Japanese horseradish (Sultana et al., 2003). Wasabi is a perennial herb with erect and simple or branched stem with green leaves in the shape of a heart. The grown out plant can reach up to $30-50 \mathrm{~cm}$ in height. It has white flowers with 4 petals. Wasabi seeds are small, about 2-3 mm long and 1 $\mathrm{mm}$ wide. The main root, sometimes described as rhizome, is usually simply shaped. After about 18 months of growing, the root reaches maturity, its shape is cylindrical to conical, curved, covered with numerous leaf scars. The length of a single root is within the range of 50 to $200 \mathrm{~mm}$, and weight from 4 to $120 \mathrm{~g}$ (Chadwick $e t$ al., 1993; Trzcinska and Hołubowicz, 2016). The beginning of Japanese horseradish cultivation in Japan dates back to the reign of Tokugawa Yasushi (Keicho era) in the years 1596-1615. The first documented place of cultivation of this plant was Utogi, visible in the upper reaches of the river Age, in Shizouk prefecture. For a well-known Japanese sashimi dish, wasabi was added around 1200 (A.D.), with the beginning of the Muromachi period (Japanese Middle Ages, shogun period), and during the Edo period (1603-1868). They were served then to soy sauce and to today's popular Japanese sushi (Anonymous, 2015). In 1902, David Fairchild was the first person who brought wasabi to the U.S. (Fairchild, 1903). The high prices of Wasabi roots have led to the search for alternative, artificial production methods. Large wasabi production is conducted in New Zealand. Unfortunately, it turned out that without the plant protection and artificial fertilizers, organic wasabi cultivation could be unprofitable. For this reason, the organic production of wasabi is already limited to solely polyethylene-coated greenhouses, in gravel collection using a hydroponic or hydrolytic system, with 
daily flooding (Palmer, 1990; Chadwick et al., 1993; Rodriguez and Punja, 2007; Yamane, 2010 a, b,). In 2012, the British farmer became first man to grow wasabi in Europe (Macdermott, 2012). In February 2017, wasabi production was commenced in Northern Ireland. At present, due to a trade secret, there are no studies conducted about wasabi production in Europe (Pullman, 2017). In Poland, there is no information about this crop production. In Japan, the crop is priced for its health benefits. Wasabi has antibacterial properties (Shin et al., 2004), and antiinflammatory effect (Uto et al., 2012). Moreover, a chemical compound extracted from wasabi called 6-(methylsulfinyl)hexyl isothiocyanate was reported to supress a breast cancer and melanoma cells development (Nomura et al., 2005) as well as human pancreatic cancer cells (Chen et al., 2014). Yamasaki et al. (2013) noted that hot water extract from wasabi leaves had an anti-obesity effect on mice. Regarding these health beneficial characteristics and taste attributes, Japanese horseradish may be used as a functional food. Wasabi leaves and stalks are partially treated as a by-product of the production process. One of the ideas for their usage can be pulping and use as dietary fiber. The total amount of fiber in the wasabi leaf and shoot was $92.3 \mathrm{~g} / \mathrm{kg}$. This mixture regulates the digestive system and especially, the proper work of the small intestine. Moreover, leaves and shoots of wasabi have a significantly lower isothiocyanate content, they are milder than roots (Wang et al., 2011). Thanks to the bactericidal properties of wasabi, the Japanese add it to their meals to prevent the food poisoning after raw fish consumption (Hodge, 1974). Recently, Japanese cuisine has become popular all over the world; it is not only interesting to consumers, but also to scientists, particularly in the western hemisphere. In Europe, it is common to use Japanese horseradish in preparing such dishes as sushi, sashimi, soba noodles or as an appetizer for baked nuts, peas, beans and potato chips. Wasabi is sold on the market in various forms. The most valuable one is the untreated root, which traditionally, is consumed just before the meal. Other forms are dry powders that must be mixed with water to release pungent substances (Eugster et al., 2011). In Japan, the production of wasabi is decreasing because of downhill in agricultural production due to the environmental pollution and contamination of the streams. For this reason, the wasabi significance in the world has been growing (Sparrow, 2004). The high demand for wasabi forces Japan to import the vegetable (Chadwick et al., 1993). Common horseradish, in Europe is often used as a substitute for wasabi (Iwashina, 2016) on account of high price of wasabi $(160 \$$ per $1 \mathrm{~kg})$. For this reason, the market is trying to replace wasabi with different mixtures made from horseradish, mustard, soy sauce with green additives (Miles and Chadwick, 2008). By law, the declaration of addition should be another product line (Eugster et al., 2011). Wasabi is also used to decorate foodstuffs with a light green colour, and as an additive in traditional and modern dishes such as Mayonnaise (Uto et al., 2012).

The cultivation of wasabi is very difficult, even in the optimal conditions. Japanese horseradish grow naturally in the mountains streams and river valleys. Currently in Japan, wasabi is grown mainly on the Izu peninsula and in the 3 prefectures: Shizuoka, Nagano and Iwate (Iwashina, 2016). It is also produced in semi-aquatic systems (Yamane, $2010 \mathrm{a}$, b)). Wasabi requires special growing conditions. In the wild, it grows in mountain valleys where the soil is fertile, sandy with excellent drainage and high water retention capacity. The best soil for wasabi is humus soil of $\mathrm{pH} 6$ to 7 (Hoshitani, 1996; Sultana and Savage, 2008). Maruyama (1965) reported that air temperature affected the growth of leaves of wasabi. Production of Japanese horseradish in mountainous areas requires an air temperature of 6 to $20^{\circ} \mathrm{C}$, preferably 8 to $18{ }^{\circ} \mathrm{C}$ (Chadwick et al., 1993). Air temperature lower than that $8{ }^{\circ} \mathrm{C}$ inhibits plant growth, at less than $5^{\circ} \mathrm{C}$, its growth is completely inhibited, At $-3^{\circ} \mathrm{C}$, the plant freezes (Adachi, 1987). Straw or plastic cover sheets must be used to prevent frost damage. In the free flow of water (Chadwick et al., 1993) the spring water is considered to be the best for growing wasabi because it is homogeneous in quality, has a consistent temperature and proper areation. If the water has a higher temperature than $12-15^{\circ} \mathrm{C}$, there may be problems with the plant's growth. As the water temperature rises, the concentration of oxygen in the water drops and eventually the plant growth can be completely inhibited. Proper mineral nutrition of wasabi is also an important factor in increasing the efficiency of its production, resulting in the receipt of high quality root (Yokogi and Ueno, 1990). Wasabi cultivation requires shading what might also control diseases. The experiment of Collins (2003) in North Carolina has shown that $80 \%$ of wasabi plants have been lost due to pathogenic agents. The disease was less widespread in more shaded areas of the plot, suggesting that additional shading can introduce adverse conditions to disease development.

Trzcinska and Holubowicz (2016) reported that Japanese horseradish might be grown under polycarbonate covers in Poland. However, they were cultivating Japanese horseradish in pots and rows. The present research study was an extension of the previous research but it was focused only on plants in rows, as more effective and cheaper in practice. In this study, chemical evaluation of the roots produced under the polycarbonate covers in Poland was done to assess the possibility of commercial production of wasabi in climatic conditions of Poland. In addition, a chemical comparison of roots produced in Poland and Japan producer was performed.

\section{Materials and Methods}

\section{Biologicalmaterial}

Seedlings of Japanese horseradish were provided from the Japanese company Miyoshi's European branch called Wasabi, located in Dorchester in the UK in May 2015 (Fig. 1). The vegetative material was multiplied by in vitro method. First, the plants were transferred to the pots and stored under the polycarbonate covers in order to adapt them to the weather conditions in Poland. After that, the plants were successfully planted in the growing medium in June 2015 and then it took almost two years to obtain mature wasabi roots. About 30 plants were stored under the covers during the winter and after producing the roots in Poland, they were investigated in November 2016. In addition, roots from a Japanese producer were evaluated and were imported directly from Japan. 
468

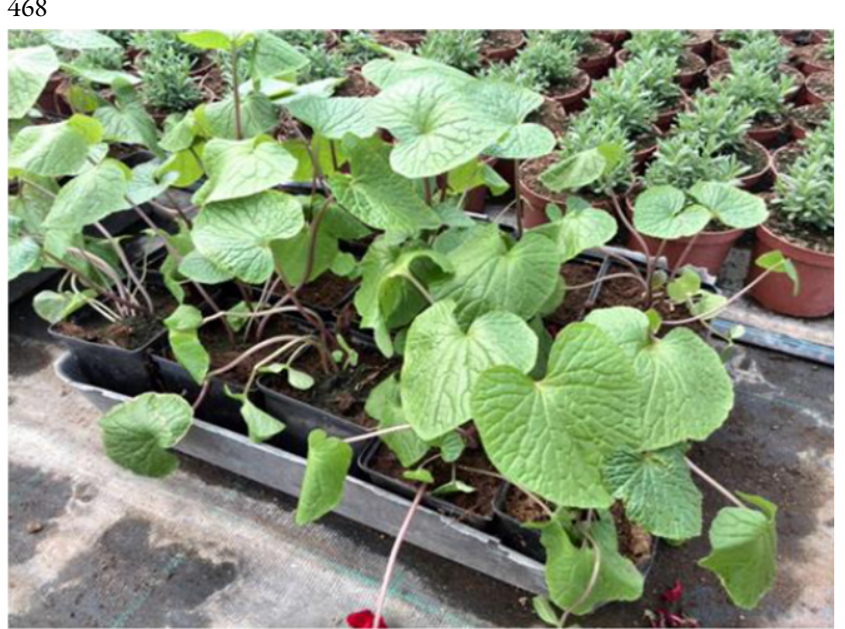

Fig. 1. Seedlings of Japanese horseradish provided from the UK, before planting in Poland

\section{Construction of the cover}

In order to conduct the experiment in the similar conditions as in the natural habitat (Japan), a carbonate greenhouse of polycarbonate boards was built. The dimension of one board was $4 \mathrm{~m} \times 10 \mathrm{~m}$. The construction was prepared to provide artificial plant growing conditions. The whole ground under cover was coated with black foil in order to prevent water loss. A thick layer $(7-10 \mathrm{~cm})$ of stones was provided and laid out on the foil to prepare appropriate drainage for the medium. Thick fraction of stones was used to avoid the water stagnation, which is undesirable in the cultivation of Japanese horseradish. In the case of low temperature, a small heater was used.

\section{Growing medium requirements}

To lead up an optimum $\mathrm{pH}$, special medium was used with an addition of $70 \%$ of phagnum peat, $25 \%$ of slowrelease pine tree bark, and a little amount of fine gravel and about $800 \mathrm{~kg}$ of fine stone per 1 ton of the soil was added to bring the cultivation of wasabi to the conditions of the mountain areas of Japan (Hoshitani, 1996; Sultana and Savage, 2008;). Additional fertilization was not added in order to maintain the natural conditions of cultivation of the crop in this study (Adachi, 1987; Chadwick et al., 1993; Yokogi and Ueno, 1990).

\section{Water requirements}

The most important factor in growing wasabi was water. The crop needs constant fresh water circulation (Suzuki, 1968). In natural conditions (Japan), it is cultivated in the valleys of mountain rivers. The water temperature should never be more than $20{ }^{\circ} \mathrm{C}$. To provide suitable water circulation and to minimize the cost of the water, a special pump device was used (Fig. 2). The tank was dug into the ground. The water from the residual tank was pumped into the drainage pipe located at the beginning of the cultivation area. The water was flowing down the hillside and it slid back into the reservoir under the influence of the slope. Every week, the water was replaced with the fresh one. To protect the culture form high temperature and sun, when necessary, an impulse sprinkler was placed in the tunnel under the polycarbonate covers.

\section{Material for chemical evaluation of the roots}

Ten roots from the current experiment under the covers and one original root imported from Japan were analysed regarding dry matter, polyphenols, antioxidant potential, reducing substances, total proteins, starch and raw fiber. All analyses were prepared at the Department of Fermentation and Biosynthesis in the Institute of Food Technology of Plant Origin at the Faculty of Food Science and Nutrition at Poznań University of Life Sciences (Poland).

\section{Chemical analysis of the roots}

For dry matter evaluation, the tested material, after crushing it in the mortar, was conducted following the method of Ładoński and Gospodarek (1986). The total polyphenol contents of wasabi roots were determined by the Folina-Ciocalteu method according to Singleton and Rossi (1965). The antioxidant potential was analysed using the method described by Re et al. (1999). The reducing substances were measured using the DNS reagent (Muller, 1959). The total proteins content was determined using Krełowska-Kułas method (1993). Hölm et al. (1986) method was used to compute the sum of carbohydrates per starch and Henneberg and Stohman method to obtain raw fiber contents (Gawęcki, 1994).

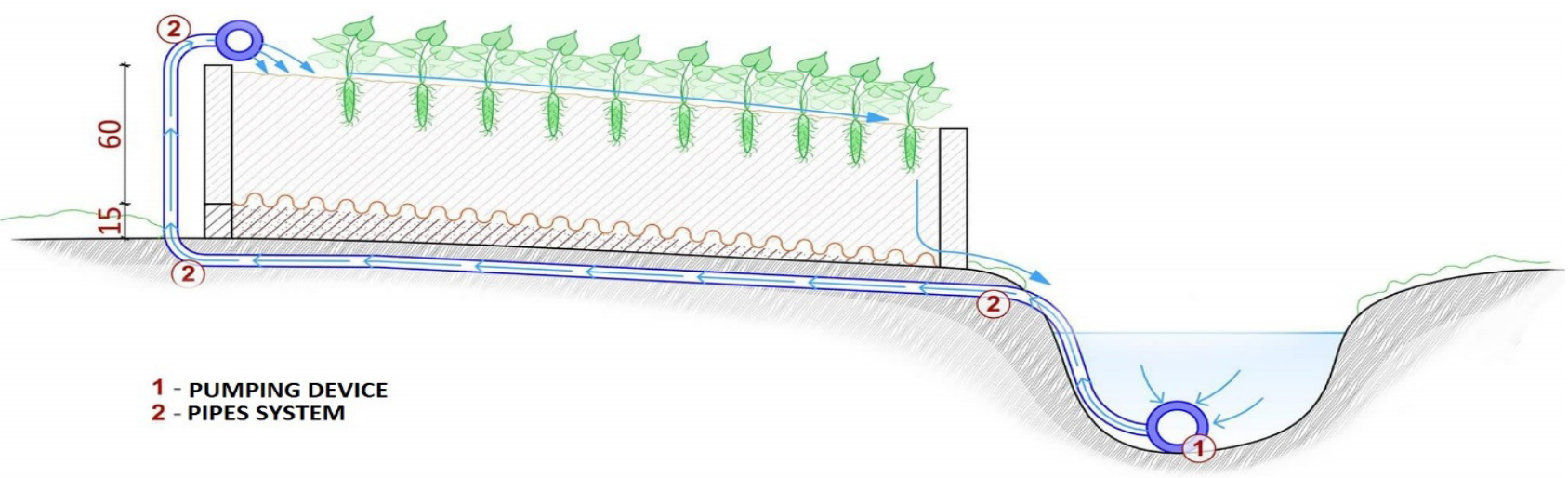

Fig. 2. A sketch of the watering system used in the polycarbonate greenhouse to grow wasabi 
Leaves and soil chemical analysis

There was also chemical evaluation of leaves and soil composition performed. The standard analysis was made at the Regional Chemical and Agricultural Station in Poznań. Organic nitrogen, $\mathrm{P}_{2} \mathrm{O}_{5}, \mathrm{~K}_{2} \mathrm{O}, \mathrm{CaO}$ and $\mathrm{MgO}$ were examined in leaves. The soil examination consisted of soil volumetric weight, $\mathrm{pH}, \mathrm{N}-\mathrm{NO}_{3}, \mathrm{P}, \mathrm{K}, \mathrm{Ca}, \mathrm{Mg}, \mathrm{Cl}$ and salinity.

\section{Statistical analysis}

The obtained data was described statistically without transformation in the computer STAT programme. The significant differences were calculated based on the Duncan's test for $\alpha=0.05$.

\section{Results}

After one and a half year of wasabi cultivation in a carbonate greenhouse in Poland, it occurred that wasabi plants were growing well and were normally developed. Trzcinska and Hołubowicz (2016) established that the commercial production of wasabi was possible in Poland. The plants survived winter 2015/2016 very well due to a higher temperature in the polycarbonate construction (never below $-3{ }^{\circ} \mathrm{C}$ ). In March 2016, the plants were blooming and in November 2016, their roots were dug out from the medium and measured. Their length varied between 7 and $14 \mathrm{~cm}$ (Fig. 3) and the Japanese wasabi root from Japan was $19 \mathrm{~cm}$ long (Fig. 4). The Polish wasabi roots were almost half of the length of the original one from Japan. In addition, a few Polish roots were deformed. They might have been damaged by black heart caused by the fungus Phoma wasabiae Yokogi.
Table 1. Comparison of the chemical contents of Polish and Japanese wasabi roots

\begin{tabular}{|c|c|c|}
\hline Compound & Polish & Japanese \\
\hline Dry matter (\%) & $30.46 b^{*}$ & $26.92 \mathrm{a}$ \\
\hline $\begin{array}{l}\text { Polyphenols } \\
\left(\mathrm{mg} \mathrm{g}^{-1} \text { d.m) }\right.\end{array}$ & $3.25 \mathrm{a}$ & $7.83 \mathrm{~b}$ \\
\hline $\begin{array}{l}\text { Antioxidant potential } \\
\qquad\left(\mathrm{mg} \mathrm{g}^{-1} \mathrm{~d} \cdot \mathrm{m}\right)\end{array}$ & $1.45 \mathrm{a}$ & $6.11 b$ \\
\hline $\begin{array}{l}\text { Reducing substances } \\
\qquad\left(\mathrm{mg} \mathrm{g}^{-1} \mathrm{~d} \cdot \mathrm{m}\right)\end{array}$ & $43.64 \mathrm{a}$ & $44.78 \mathrm{~b}$ \\
\hline Starch (mg g $\left.{ }^{-1} \mathrm{~d} . \mathrm{m}\right)$ & $568.07 \mathrm{a}$ & $569.41 \mathrm{a}$ \\
\hline Total proteins (\% d.m) & $12.14 \mathrm{a}$ & $13.84 b$ \\
\hline Fiber (\% d.w) & $3.94 \mathrm{a}$ & $4.13 \mathrm{a}^{*}$ \\
\hline
\end{tabular}
to the Duncan's test for $\alpha=0.05$

The main difference between roots produced in Poland and in Japan was the amount of dry matter in the Polish root, the dry matter was $30.46 \%$ and in Japanese one $26.92 \%$. The raw fiber and starch contents were the same in both roots. In the Japanese root, the total proteins contents and reducing substances contents were higher than in the Polish one. Polyphenols and antioxidant potential were higher in the Japanese root than in the Polish ones (Table 1).

After one and a half year of production, the wasabi leaves produced in Poland had the highest content of $\mathrm{CaO}$ (3.22\%) and organic nitrogen (3.16\%) whereas the lowest content of $\mathrm{P}_{2} \mathrm{O}_{5}(0.46 \%)$. (Table 2$)$. Regarding to soil chemical composition (Table 3), the highest content of $2988 \mathrm{mg} \mathrm{dm}^{-3}$ soil of Ca was recorded in contrast to $\mathrm{Cl}$ content $\left(<21.3 \mathrm{mg} \mathrm{dm}^{-3}\right.$ soil $)$.

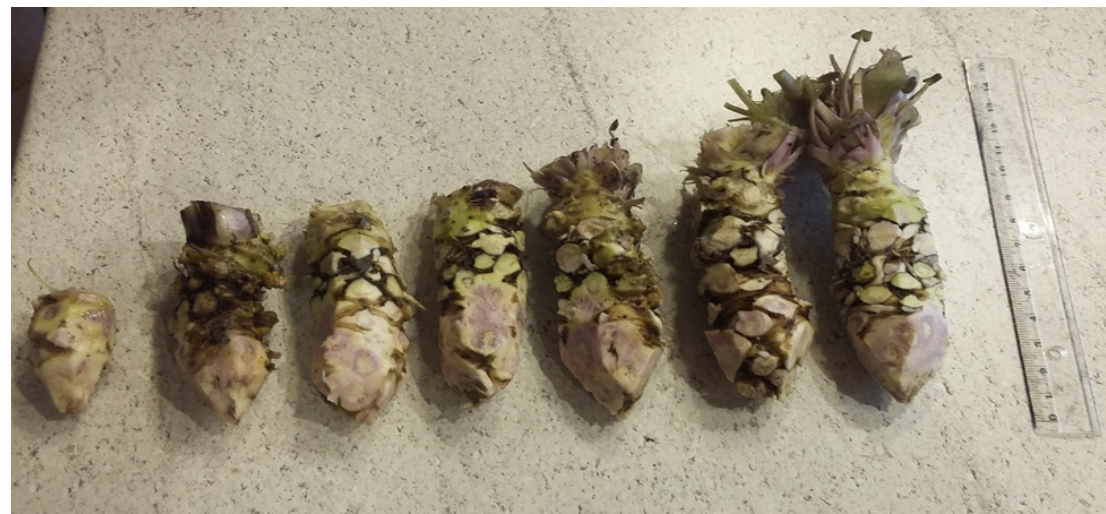

Fig. 3. Measurement of the Polish wasabi roots dug out from the medium

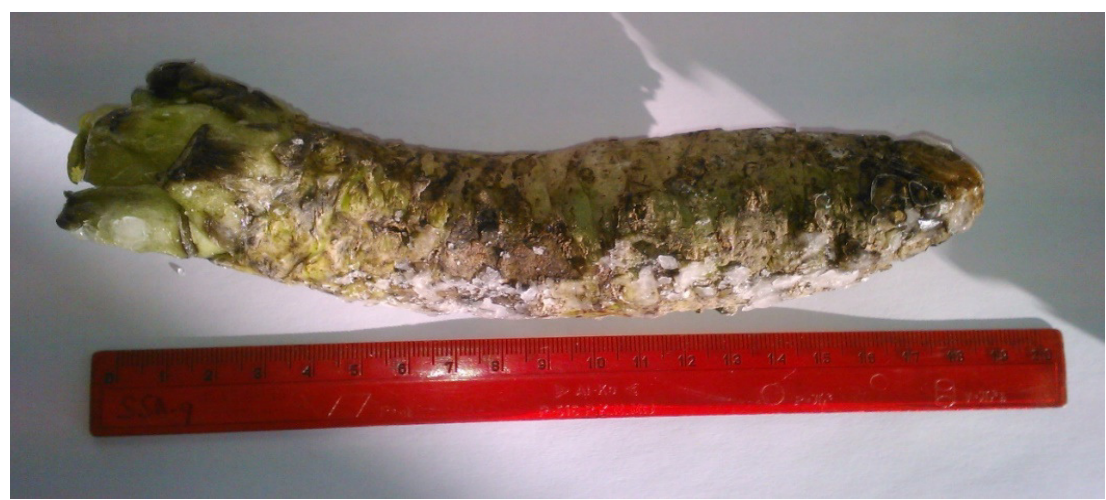

Fig. 4. Japanese wasabi root obtained from Japan 
Table 2. Contents of selected components in the leaves of Polish wasabi plants

\begin{tabular}{cccccc}
\hline \multirow{2}{*}{ Leaves } & \multicolumn{3}{c}{ Components (\%) d.m. } & & \\
\cline { 2 - 6 } & $\mathrm{N}$ org & $\mathrm{P}_{2} \mathrm{O}_{5}$ & $\mathrm{~K}_{2} \mathrm{O}$ & $\mathrm{CaO}$ & $\mathrm{MgO}$ \\
\hline $\begin{array}{c}\text { Leaves from the rows of wasabi } \\
\text { cultivation }\end{array}$ & 3.16 & 0.46 & 2.42 & 3.22 & 0.77 \\
\hline
\end{tabular}

Table 3. Contents of selected components in soil after one and a half year of the cultivation of Japanese horseradish

\begin{tabular}{|c|c|c|c|c|c|c|c|c|c|}
\hline \multirow{2}{*}{ Soil } & \multirow{2}{*}{$\begin{array}{l}\text { Volumetric weight } \\
\qquad \mathrm{g} \mathrm{dm}^{-3}\end{array}$} & \multirow{2}{*}{$\mathrm{pH} \mathrm{H} \mathrm{H}_{2} \mathrm{O}$} & \multicolumn{6}{|c|}{ Components ( $\mathrm{mg} \mathrm{dm}^{-3}$ soil) } & \multirow{2}{*}{$\begin{array}{c}\text { Salinity } \\
\mathrm{g} \mathrm{NaCl} \mathrm{dm}^{-3}\end{array}$} \\
\hline & & & $\mathrm{N}-\mathrm{NO}_{3}$ & $\mathrm{P}$ & $\mathrm{K}$ & $\mathrm{Ca}$ & $\mathrm{Mg}$ & $\mathrm{Cl}$ & \\
\hline $\begin{array}{l}\text { Soil from the rows } \\
\text { of wasabi cultivation }\end{array}$ & 880 & 8.0 & 26 & 40 & 47 & 2988 & 528 & $<21.3$ & 0.38 \\
\hline
\end{tabular}

\section{Discussion}

Japanese horseradish has been one of the most important spice vegetables in Japan and other Far East countries (Hoshitani, 1996). In Japan, in 2014, there were over 300 ha of commercial wasabi plantations. Moreover, its wholesale price on the Japanese market in 2015 was over 160 USD per kilogram (Hołubowicz and Rochowiak, 2016). The high price of wasabi caused by the fact that despite the vast research and many studies, wasabi is still difficult to multiply through seeds and, therefore, commercial transplants available today on the market are expensive. No wonder that in many other countries, there has been a growing interest to introduce and produce this crop (Sparrow, 2004). Additionally, growers are ready to pay a lot for good-quality, healthy wasabi transplants (Gittleson, 2014). In the light of current knowledge, there are no complete studies on wasabi roots chemical contents. Although, there have been quite a few papers on a single chemical compounds present in the root (Depree et al., 1998; Sultana, 2002; Sultana et al., 2003; Hasoya et al., 2005; Kwiatkowska, 2007; Nagai et al., 2010; Uto et al., 2012).

The present research with wasabi plants was conducted first time in Poland. After one and half year, it was possible to obtain good quality roots which, might be processed into a paste or powder. The carried out experiment confirmed that Japanese horseradish production under the covers in climatic conditions of Poland might be done and led to production of good quality roots. However, the length of a Polish root produced under the covers was different from the Japanese one. It was almost two times smaller than the Japanese one. Possible explanation for this inconvenient might be the lacking of fresh water, the diseases, the specific growing medium requirements or the vegetation period as well as the different climatic conditions. In nature, wasabi is cultivated in the shady river valleys of Japanese mountains. Although, the Polish roots were smaller, their chemical analyses showed that some of the chemical substances were quantitatively almost the same as were in the Japanese roots. In spite of higher contents of total proteins and reducing substances which were $13.84 \%$ of dry weight and $44.78 \mathrm{mg}$ $\mathrm{g}^{-1}$ in Japanese root respectively, fiber, starch, dry matter were similar. However, polyphenols and antioxidant potential were higher than in the Polish ones.

The main difference in leaves analysis was amount of $\mathrm{CaO}$ which was the $9.66 \%$ of dry weight after half a year of wasabi cultivation (Trzcinska and Hołubowicz, 2016). In this study, the amount was $3.22 \%$ of dry weight after one year and a half of the experiment. Also recorded $\mathrm{MgO}$ and $\mathrm{K}_{2} \mathrm{O}$ amounts decreased after one year and a half. The organic nitrogen and $\mathrm{P}_{2} \mathrm{O}_{5}$ slightly increased.

Based on the results of the experiment carried out by Trzcinska and Holubowicz (2016), it was also possible to compare the soil composition with the present study. In conclusion, volumetric weight, $\mathrm{P}, \mathrm{K}, \mathrm{Mg}$ and $\mathrm{Cl}$ contents were higher in the soil from the present study. The $\mathrm{N}-\mathrm{NO}_{3}$ and $\mathrm{Ca}$ contents, however, were lower in the previous experiment. Moreover, $\mathrm{pH}$ was the same and salinity was higher. When the crop was grown for one year and a half, as in our study, plants had higher demand for $\mathrm{N}-\mathrm{NO}_{3}$ and $\mathrm{Ca}$ and lower demand $\mathrm{P}, \mathrm{K}, \mathrm{Mg}$ and $\mathrm{Cl}$. The high demand of $\mathrm{N}-\mathrm{NO}_{3}$ in the present study could come from the observed high fresh tissue production. This corresponds to the study of Martin and Deo (2000), who in their study reported up to $5 \mathrm{~kg} / \mathrm{m}^{2}$ of fresh wasabi material produced in the first year and $6 \mathrm{~kg} / \mathrm{m}^{2}$ in the second year. The same authors also confirmed the high amount of $\mathrm{Ca}$ in the soil in the shade house of wasabi plantation. The optimal $\mathrm{pH}$ recommended by the authors was 6.3 at the top layer of the soil $(0-15 \mathrm{~cm})$ and 6.0 in the deeper layer $(15-30 \mathrm{~cm})$. However, other authors reported the optimal $\mathrm{pH}$ to be from 6 to 7 (Hoshitani, 1996; Sultana, 2002) or 6.5-7.5 (Ma et al., 2009).

Park and Lee (2015) were also studying chemical composition of wasabi leaves. They measured basic chemical elements and showed that the leaves were alkaline because of the highest contents of $\mathrm{K}$ followed by $\mathrm{Ca}, \mathrm{P}$ and $\mathrm{Mg}$. They also measured the contents of sinigrin and allyisothiocyanate which are health promotion chemical compounds. Most of the research on wasabi has been focused on allyl isothiocyanate compound, which is presented in every morphological part of the plant (roots, stems, leaves). The results of different studies suggested that component could be effective in killing Helicobacter pylori (Shin et al., 2004) or used as a cancer chemopreventive phytochemical (Zhang, 2010) and antiplatelet activity. In the conducted study, there was no such chemical analysis performed but future researches are focused on this field.

Oguni et al. (2005) carried out the experiment in Japan which focused on the impact of environmental controls on the wasabi growth. The cultivation was conducted under the covers, similar to this study. In the summer, fans were used to exchange the air masses and to cool the room on 
account of temperature never exceeding $35^{\circ} \mathrm{C}$. In the winter, however, heaters were used, thanks to which the air temperature did not fall below $13{ }^{\circ} \mathrm{C}$. Experiment showed the importance of the air temperature control. Unfortunately, in current study, conducted in Poland, full control of temperature was not possible due to prolonged unfavourable temperatures in the winter of 2016/2017. For economic reasons, it was necessary to interrupt constant heating of the structure. Despite the negative winter temperatures, wasabi plants have taken the spring growth and bloomed. However, it must be noted that the flowering of 2017 was much weaker than the flowering of 2016. Unfavourable temperatures had no major impact on the development of the Japanese horseradish, although they were weakened. This observation will be evaluated in autumn 2017.

Yamane et al. (2016) suggested that the genetic differences between the related species of Eutrema wasabi from Japan and Eutrema yinnanense from China are the result of evolution over many years. This has led to a change in the uses of wasabi and its chemical composition and properties in both countries. The results of this study might determine whether the cultivation in Poland has any effect on the change in chemical composition, properties and application of Japanese horseradish. Only repeating these tests for several consecutive years on the plants of the same variety might give a credible answer.

\section{Conclusions}

Production of Wasabi japonica Matsumara could be successfully done in Poland. In the climatic conditions of Poland, special construction must be used, followed by specific water, temperature and insolation conditions. The total proteins, polyphenols, antioxidant potential and reducing substances contents were smaller in Polish roots than in the Japanese one. The other chemical compounds in the Polish roots were similar to the Japanese one.

\section{References}

Adachi S (1987). Wasabi saibai. Shizuoka, Japan. Shizuoka Prefecture Agricultural Experiment Station.

Anonymous (2015). Materials from Museum in Daio Wasabi Farm (in Japanese).

Chadwick CL, Lumpkin TA, Elberson LR (1993).The botany, uses and production of Wasabia japonica (Miq.) (Cruciferae) Matsum. Economic Botany 47:113-135.

ChenYJ, Huang YC, Tsai TH, Liao HF (2014). Effect of wasabi component

6-(methylsulfinyl) hexyl isothiocyanate and derivatives on human pancreatic cancer cells. Evidence-Based Complementary and Alternative Medicine ID 494739.

Collins R (2003). Growing Wasabi in Western North Carolina. Retrieved 2017 March 15 from https://projects.ncsu.edu/cals/specialty_crops/ publications/reports/collins2.html.

Depree JA, Howard TM, Savage GP (1998). Flavour and pharmaceutical properties of the volatile sulphur compounds of wasabi (Wasabia japonica).Food Research International 31(5):329-337.
Eugster A,Murmann P, Borer M, Kaenzig A (2011). A real-time polymerase chain reaction (PCR) method for the detection of wasabi (Eutrema wasabi) in foods. European Food Research and Technology 232:929934.

Fairchild D (1903). Wasabi, the horseradish of the Japanese. Three new plant introductions from Japan. US Department of Agriculture, Bureau of Plant Industry Bulletin(42):20-22

Gawęcki K (1994). Ćwiczenia z żywienia zwierząt i paszoznawstwa [Exercises from animal feeding and Fodder Science] (in Polish). Wydawnictwo Akademii Rolniczej. Ed Office of PULSPoznań.

Gittleson K (2014). Wasabi: Why invest in 'the hardest plant to grow'? Retrieved 2017 April 7 from http://www.bbc.com/news/business29082091.

Hosoya T, Yun YS, Kunugi A (2005). Five novel flavonoids from Wasabia japonica. Tetrahedron 61 (29)::7037-7044

Hodge WH (1974): Wasabi-Native Condiment Plant ofJapan. Economic Botany 28:118-129.

Hotubowicz R, Rochowiak R (2016). Japan-master breeding ( in Polish). Warzywai Owoce Miękkie2:56-59.

Hoshitani Y (1996). From Wasabi Cultivation to Processing and Selling (in Japanese). Agriculture Mountain Fishing Village Culture Association. ISBN: 978-4540-95090-2.

Hölm J, Björck I, Drews A (1986) A rapid method for the analysis of starch. Starch-Stärke(1986) 38:224226.

Iwashina T (2016). Eutrema japonicum. Curtiss's Botanical Magazine $33(3): 217-225$.

Krełowska-Kułas M (1993). Badanie jakości produktów spożywczych [Examining the quality of food products] PWE Polish Economy Society Publ Office, Warszawapp 32-37.

Kwiatkowska E (2007). Isothiocyanates in wasabi (Wasabia japonica) (in Polish).Postępy Fitoterapii. Borgis 1:7-11.

Ładoński W, Gospodarek T (1986). Podstawowe metody analityczne produktów żywnościowych [Basic analytical methods of food products ].PWN.State Research Editorial Office, Warszawa.

Ma DX et al. (2009). Wasabia japonica. In: Cultivation of Chinese Vegetables (in Chinese), Second Ed. China Agriculture Press, Beijing pp 316-317.

Macdermott K (2012). British farmer becomes first in Europe to grow Japanese superfood wasabi. Retrieved 2017 April 7 from http://www.dailymail.co.uk/news/article-2216648/British-farmerflavour-chefs-Europe-grow-Japanese-superfood-wasabihtml.

Martin RL, Deo B (2000). Preliminary assessment of the performance of soil-grown wasabi (Wasabiajaponica (Miq.) Matsum.) in New Zealand conditions. New Zealand Journal of Crop and Horticultural Science 28(1):45-51.

Maruyama T (1965). Studies on thickening growth of wasabi (in Japanese). Bulletin of Shizuoka Agricultural Experimental Station 10:131-145.

Miles CA, Chadwick CI (2008). Growing wasabi in the Pacific Northwest. Washington State University Extension

Muller GL (1959). Use of dinitrosalicylie acid reagent for determination of reducingsugar. Analytical Chemistry 31(3):426-428.

Nagai M, Akita K, Yamada, K, OkunishiI (2010). The effect of isosaponarin 
472

isolated from wasabi leaf on collagen synthesis in human fibroblasts and its underlying mechanism. Journal of Natural Medicines 64:305-312.

Nomura T, Shinoda S, Yamori T, Sawaki S, Nagata I, Ryoyama K, Fuke Y (2005). Selective sensitivity to wasabi-derived 6-(methylsulfinyl)hexyl isothiocyanate of human breast cancer and melanoma cell lines studied in vitro. Cancer Detection and Prevention 29(2):155-160.

Oguni S, Kakibuchi K, Katayama Y (2005). Effects of Environmental Controls on the Growth of Wasabi (Eutrema japonica (Miq.) Koidz.) in a Nutrient Solution Cultivation System. Environmental Control in Biology 43(3):181-191.

Palmer J (1990). Germination and growth of wasabi (Wasabia japonica (Miq.) Matsumara). New Zealand Journal of Crop and Horticultural Science 18:161-164.

Park SJ, Lee HY (2015). Component analysis and antioxidant activity of Wasabi japonica Matsum leaves. Korean Journal of Medicinal Crop Science 23(3):207-213.

Pullman N (2017). Wasabi production opens up in Northern Ireland. Retrieved 2017 February 7 from http://www. fruitnet.com/fpj/article/171256/wasabi-production-opens-up-innorthern-ireland.

ReR, Pellegrini N, ProteggenteA, Pannala A, YangM, Rice-Evans C (1999). Antioxidant activity applying an improved ABTS radical cation decolorization assay. Free Radical Biology and Medicine 26(9/10):12311237.

Rodriguez G, PunjaZK (2007). Root infection of wasabi (Wasabiajaponica) by Pythium species. Canadian Journal of Plant Pathology 29:79-83.

Shin IS, Masuda H, Naohide K (2004). Bactericidal activity of wasabi (Wasabia japonica) against Helicobacter pylori. International Journal of Food Microbiology 94(3):255-261.

Singleton VL, Rossi JA (1965). Colorimetry of total phenolics with phosphomolybdic-phosphotungstic acid reagents. American Journal of Enology and Viticulture 16(3):144-158.

Sparrow A (2004). Horticulturist DPIWE Tasmania Westbury Road. The New Crop Industries Handbookpp 98-103.

Sultana T (2002). Effects of fertilisation on the allyl isothiocyanate profile of above-ground tissues of New Zealand-grown wasabi. Journal of the Science of Food and Agriculture 82(13):1477-1482.
Sultana T, Savage GP, McNeil DL, Porter NG, Clark B (2003). Comparison of flavour compounds in wasabi and horseradish. Journal of Food, Agriculture and Environment (1):117-121.

Sultana T, Savage GP (2008). Wasabi-Japanese Horseradish. Bangladesh Journal of Scientific and Industrial Research 43(4):433-448.

SuzukiM(1968). Wasabi. Manuscript. Kyoto University,Japan.

Trzcinska P, Hołubowicz R (2016). Cultivation of Japanese horseradish (Wasabia japonica (Miq.) Matsumara) under polycarbonate cover in Poland. Scientific Proceedings of the $5^{\text {th }}$ International Scientific Horticulture Conference, Slovakia, Nitra pp 136-142.

Uto T, Hou DX, Morinaga O, Shoyama Y (2012). Molecular mechanisms underlying anti-inflammatory actions of 6-(methylsulfinyl) hexyl isothiocyanate derived from wasabi (Wasabia japonica). Advances in Pharmacological Sciences ID 614046.

Wang X, Zhou H, Liu X (2011). Preliminary study on the functional elements in the mixture of wasabi leaf and leaf stalk and its catharsis effect.Journal of Chongqing Medical University 36(11):1347-1349.

Yamane K (2010a). Origin, production, and consumption of ordinary vegetable and fruit - Wasabi (part I). (in Japanese). Food Preservation Science 36:189-196.

Yamane K (2010b). Origin, production, and consumption of ordinary vegetable and fruit - Wasabi (part II). (in Japanese). Food Preservation Science 36:243-247.

Yamane K, Sugiyama Y, Lu Y, Lű N, Tanno K, Kimura E, Yamaguchi H (2016). Genetic differentiation, molecular phylogenetic analysis, and ethnobotanical Study of Eutrema japonicum and E. tenue in Japan and E. yunnanense in China. The Horticulture Journal 85(1):46-54.

Yamasaki M, Ogawa T, Wang L, Katsube T, Yamasaki Y, Sun X, Shiwaku $\mathrm{K}$ (2013). Anti-obesity effects of hot water extract from wasabi (Wasabia japonica Matsum.) leaves in mice fed high-fat diets. Nutrition Research and Practice 7(4):267-272.

Yokogi K, Ueno R (1990). Special products series no. 34. Wasabi: a profitable side business in the mountains, 3rd edition. Noosangyoson Bunkakyo. Agricultural and Fishing Villages Association Publ, Tokyo.

Zhang Y (2010). Allyl isothiocyanate as a cancer chemopreventive phytochemical. Molecular Nutrition and Food Research 54(1):127135. 